\title{
FREE AMINO ACIDS IN THE OVIDUCT FLUID OF THE EWE*
}

\author{
J. L. PERKINS $\dagger$ AND LEMUEL GOODE \\ Department of Animal Science, North Carolina Agricultural Experiment Station, \\ Raleigh, U.S.A.
}

(Received 22nd February 1967)

\begin{abstract}
Summary. Oviduct fluid was collected by means of a cannula sutured into the oviduct. A composite fluid sample representing all stages of the oestrous cycle contained lysine, histidine, arginine, aspartic acid, serine, glutamic acid, glycine, alanine, valine, methionine, isoleucine, leucine, tyrosine, phenylalanine and cystine. Cystine was not detected in fluid collected during an interval 1 day before until 2 days after the onset of oestrus. Five unidentified compounds were present in all fluid samples analysed.
\end{abstract}

Data on free amino acids were obtained on three samples of oviduct fluid collected from eight mature Dorset ewes. An oviduct of each ewe was cannulated according to the procedures described by Perkins, Goode, Wilder \& Henson (1965). Fluid was removed from the collection chambers at 24-hr intervals and was stored frozen until analysis. Oestrus was determined with vasectomized rams.

All stages of the oestrous cycle were represented in Sample 1, which consisted of oviduct fluid pooled from four ewes. Approximately equal amounts of fluid were selected at random from the follicular and luteal phases of the cycle of each ewe. Samples 2 and 3 were collected during a 4-day period that began 1 day before the onset of oestrus. The rate of fluid secretion by the ewe oviduct is at a maximum during this period (Perkins et al., 1965). Sample 2 consisted of $5.0 \mathrm{ml}$ of pooled fluid from two ewes that showed natural oestrous periods, whereas Sample 3 consisted of $5.0 \mathrm{ml}$ of pooled fluid from two ewes whose oestrous periods had been synchronized with progesterone and pregnant mares' serum as described by Perkins \& Goode (1966). All ewes contributed approximately equal amounts of fluid to their respective samples. In Samples 2 and 3, the danger of bacterial growth was reduced by the daily addition of $0.1 \mathrm{ml}$ of a $1 \%$ aqueous solution of merthiolate (Powell \& Jamieson, 1938) to each collection chamber. Fluid was also examined by standard bacteriological techniques, however, and contamination was not encountered during the experiment.

* Published with the approval of the Director of Research as Paper No. 2255 of the Journal Series.

$\dagger$ Present address: Department of Animal Science, University of Arkansas, Fayetteville, Arkansas. 
Amino acid determinations were made with a Beckman 120B Amino Acid Analyzer according to procedures outlined for blood plasma (Stein \& Moore, 1954; Spackman, 1962). Basic and acidic amino acids were determined on $15 \mathrm{~cm}$ and $150 \mathrm{~cm}$ columns of Beckman Ion Exchange Resin, Types 15A and $150 \mathrm{~A}$, respectively. The method used would have detected seventeen amino acids and these, along with their concentrations, are shown in Table 1.

TABLE 1

FREE AMINO ACIDS IN THE OVIDUCT FLUID OF EWES

\begin{tabular}{|c|c|c|c|}
\hline Amino acids $(\mathrm{mg} / 100 \mathrm{ml})$ & $\begin{array}{l}\text { Sample 1: } \\
\text { all stages of } \\
\text { oestrous cycle }\end{array}$ & $\begin{array}{c}\text { Sample 2: } \\
\text { natural } \\
\text { oestrus }\end{array}$ & $\begin{array}{c}\text { Sample 3: } \\
\text { synchronized } \\
\text { oestrus }\end{array}$ \\
\hline $\begin{array}{l}\text { Lysine } \\
\text { Unknown 1* } \\
\text { Histidine } \\
\text { Unknown } 2 \\
\text { Ammonia } \\
\text { Arginine } \\
\text { Unknown } 3 \\
\text { Aspartic acid } \\
\text { Unknown } 4 \\
\text { Threonine } \\
\text { Serine } \\
\text { Glutamic acid } \\
\text { Proline } \\
\text { Unknown 5† } \\
\text { Glycine } \\
\text { Alanine } \\
\text { Half cystine } \\
\text { Valine } \\
\text { Methionine } \\
\text { Isoleucine } \\
\text { Leucine } \\
\text { Tyrosine } \\
\text { Phenylalanine }\end{array}$ & $\begin{array}{c}3.29 \\
+ \\
0.39 \\
+ \\
+ \\
0.92 \\
+ \\
0.75 \\
+ \\
0.00 \\
0.15 \\
1.81 \\
0.00 \\
+ \\
6.04 \\
3.26 \\
0.73 \\
3.78 \\
0.63 \\
0.97 \\
2.24 \\
0.51 \\
0.89\end{array}$ & $\begin{array}{l}1.68 \\
+ \\
0.39 \\
+ \\
+ \\
1.04 \\
+ \\
0.24 \\
+ \\
0.00 \\
0.55 \\
1.06 \\
0.00 \\
+ \\
6.22 \\
1.50 \\
0.00 \\
1.39 \\
0.24 \\
0.60 \\
1.17 \\
0.63 \\
0.55\end{array}$ & $\begin{array}{l}3 \cdot 37 \\
+ \\
0.81 \\
+ \\
+ \\
2 \cdot 14 \\
+ \\
0.37 \\
+ \\
0.00 \\
0.88 \\
2 \cdot 12 \\
0.00 \\
+ \\
9.98 \\
2.06 \\
0.00 \\
1.77 \\
0.37 \\
0.92 \\
1.80 \\
0.82 \\
0.76\end{array}$ \\
\hline
\end{tabular}

* Presence of unknowns and ammonia is indicated by + sign.

+ Unknown 5 was recorded in the location of proline but did not exhibit the characteristic yellow colour of the proline when reacted with ninhydrin.

Fifteen amino acids were present in varying concentrations in Sample 1, in which all stages of the oestrous cycle were represented. Cystine was not detected in Samples 2 and 3, where fluid collection was limited to 1 day before until 2 days after the onset of oestrus. Either merthiolate interfered with the determination of cystine in these samples or cystine may be associated with the progestational rather than oestrogenic phase of the cycle. More information is needed on this point. Proline and threonine were not present in detectable amounts, and the concentration of glycine was higher than other amino acids in all samples.

Alanine, glycine, glutamic acid, valine, serine, leucine, lysine and aspartic acid have been reported in rabbit oviduct fluid (Gregoire, Gongsakdi \& Rakoff, 1961; Mastroianni \& Wallach, 1961; Hamner \& Williams, 1965). Gregoire et al. (1961) and Hamner \& Williams (1965) did not find proline and threonine in rabbit oviduct fluid, and Gregoire et al. (1961) reported that the concentration of glycine exceeded that of other amino acids. 
Quantitative comparisons among the three fluid samples are not justified since the data are limited and the stage of cycle and hormone treatment varied between samples.

Five unidentified compounds were also present in ewe oviduct fluid. Both amino acids and unknowns are listed in Table 1 according to their elution sequence. The same unknowns, based on elution volume, were present in all fluid samples.

\section{REFERENCES}

Gregorre, A. T., Gongsakdi, D. \& Rakoff, A. E. (1961) The free amino acid content of the female genital tract of the rabbit. Fert. Steril. 12, 322.

Hamner, C. E. \& Williams, W. L. (1965) Composition of rabbit oviduct secretions. Fert. Steril. 16, 170.

Mastroianni, L., JR. \& Wallach, R. G. (1961) Effect of ovulation and early gestation on oviduct secretions in the rabbit. Am. F. Physiol. 200, 815.

Perkins, J. L. \& Goode, L. (1966) Effects of stage of the estrous cycle and exogenous hormones upon the volume and composition of oviduct fluid in ewes. 7. Anim. Sci. 25, 465.

Perkins, J. L., Goode, L., Wilder, W. A., JR. \& Henson, D. B. (1965) Collection of secretions from the oviduct and uterus of the ewes. F. Anim. Sci. 24, 383.

Powell, H. M. \& Jamieson, W. A. (1938) On the efficacy of merthiolate as a biological preservative after ten years use. Proc. Indiana Acad. Sci. 47, 65.

Spackman, D. H. (1962) Instruction Manual, Model 120B Amino Acid Analyzer. Beckman Instruments, Inc., Palo Alto, California.

Stein, W. H. \& Moore, S. (1954) The free amino acids of human blood plasma. F. biol. Chem. 211, 915. 